\title{
Legal Analysis of the Transition of the Determination of NJOP to Local Governments in Determining Tax Value in the Deed of Selling
}

\author{
Albert Lodewyk Sentosa Siahaan ${ }^{1}$, Budiman Ginting ${ }^{2}$, Muhammad Yamin ${ }^{3}$, \\ Keizerina Devi ${ }^{4}$ \\ ${ }^{1}$ PhD in Law Program, Graduate School, Universitas Sumatera Utara (USU-Medan), Medan, North Sumatera, \\ Indonesia \\ ${ }^{2,3,4}$ Universitas Sumatera Utara (USU-Medan), Medan, North Sumatera, Indonesia \\ Email: albertlodewyksiahaan@gmail.com
}

\begin{abstract}
Selling Value of Tax Object is the value that becomes the basis for calculating tax in the deed of sale if the transaction price is below the NJOP price. By knowing the tax base, the transfer of land and building taxes consisting of PPh, PPN and PPnBM and BPHTB can be determined. The determination of NJOP which was previously determined by the central government and is a central government tax is transferred to local governments based on the Law on Regional Taxes and Regional Levies. Why was the determination of the NJOP transferred from the central government to the local government? This study uses a normative juridical research method by collecting literary materials from books, laws, articles and other legal materials. The results of this study indicate that the determination of NJOP is transferred to the local government followed by two other types of taxes PBB P2 and BPHTB due to the need for acceleration of regional development and regional autonomy and decentralization. The object of tax, namely land and buildings, is an object that cannot.be moved because.it is included in the category of immovable objects, it is appropriate to be used as a local tax because the local government located in each region is more aware of the condition of the tax object compared to the central government. So that the transition referred to in the Law on Regional Taxes and Regional Levies covers the entire management, namely, implementation, determination of NJOP, collection of the tax.
\end{abstract}

Keywords: Legal Analysis, Transition of NJOP Determination, Local Government, Atka Buying and Selling

\section{INTRODUCTION}

Tax is a mandatory contribution to the state that is owed by an individual or entity that is coercive under the law, with no direct compensation and is used for state needs for the greatest prosperity of the people (United Nations and City, no date). Currently, for the government, taxes are the main and potential source of revenue and one of them is BPHTB as a local tax paid by the buyer in the deed of sale and purchase. Sales Value of Tax Objects can be defined as the average price obtained from buying and selling transactions that occur fairly. There is a lot of diversity and differences in land and buildings in Indonesia, and the NJOP plays an important role in calculating the PBB owed which in the future will be the obligation of the taxpayer to pay it ${ }^{1}$. The determination of the NJOP is based on a property assessment carried out by the central government in this case KPP Pratama with the assistance of the local government and even the community directly

In the 17 th century onwards, when Indonesia was under Dutch and British colonial rule, taxes on land were officially enforced under a standard name. Various types of taxes on land and buildings are then applied in Indonesia under various names and rules, where the provisions on these taxes are adjusted by the government
${ }^{1}$ Ovelia Veradina Imbing, Analisis Penetapan NJOP dan implikasi terhadap penerimaan PBB di Kota Manado,
ISSN 2303 -1174, Jurnal EMBA, Vol. 1 No. 3 Juni 2013, Hal. 485 
whose provisions on taxes are adjusted by the government in power at certain times in Indonesia ${ }^{2}$.

In Indonesian history, Dutch troops led by Cornelius de Houtman came to Indonesia with the intention of trading in Indonesia at the end of the 16th century ${ }^{3}$. In 1602 the "Verenigde Oost-Indische Compagnie" was founded, abbreviated as VOC or kompeni, which was a trade alliance. The Company obtained monopoly rights from the Dutch government, so that only the Company was allowed to trade between the Cape of Good Hope and the Megalhaes Strait. For this reason, the Company obtained power from the Dutch government, so that only the Company was allowed to trade between the Cape of Good Hope and the Strait of Magellan. For this reason, the Company gained power as a government from the Dutch government. The goal is to get as much profit as possible. The Company carried out the Verplicte leverantien regulation on the colonized communities in the archipelago, namely the mandatory gift, an average of $20 \%(1 / 5)$ of all production ${ }^{4}$. After Indonesia's independence, various types of taxes that were previously levied by the Dutch and Japanese colonial governments were still levied by the Indonesian government, including Income Tax, Company Tax, the 1921 Stamp Duty Rules and Land Tax.

Sales.Value of Tax Objects is the.average price obtained.from buying and selling transactions, Sales Value of Tax Objects is determined by using a price comparison with other similar objects or the acquisition value or Sales Value of substitute Tax Objeks ('Juridical Review of Collection of Income Tax on Sales Transactions) Buy Land and/or Building Rights', 2018).

The Sales Value of the Tax Object is the basis for the imposition of BPHTB in the deed of sale and purchase. With the enactment of Law Number 28 of 2009 concerning Regional Taxes and Regional Levies (UU PDRD), PBB P2 and BPHTB become the authority of the Regional Government, in this case the City or Regency Government. The authority in managing PBB P2 and BPHTB includes the imposition and collection of taxes and the determination of NJOP.

\section{RESEARCH METHODS}

This research uses normative research, namely legal research that uses secondary data sources or data obtained through library materials by examining research on legal principles, legal sources, legal theories taken from books and legislation. as well as regulations under the law such as presidential regulations, government regulations, ministerial regulations and regional regulations related to this article.

\section{DisCUSSION}

The decentralization of autonomous regions is carried out so that each region can also develop according to its own abilities and not always depend on the central government. Therefore, autonomous regions can have their own ability to manage and regulate their own households by maximizing available sources of income. All wealth controlled by the region with the existing authority limits, including the authority limited by Law Number 28 of 2009 concerning Regional Taxes and Regional Levies which is then used to provide financing for all needs in the context of administering their own household affairs.

The implementation of regional autonomy which gives greater authority to the regions for the implementation of regional government based on services to each of the regional communities. This is because the Regional Original Revenue (PAD) is still not maximized, the regional tax base is still limited, the number of problematic Regional Regulations regarding collection, and the weak supervision of regional levies due to the repressive system of supervision as well as the application of sanctions that have not been maximized. Regional.Tax, hereinafter referred to as tax, is a mandatory contribution to the region owed by an individual or entity that is coercive under the law, without receiving direct compensation and is used for the region for the greatest prosperity of the people.

The concept of regional autonomy is that the authority to carry out functions or manage the region independently does not just come, but is the best decision in making political decisions taken to improve the effectiveness of governance, public services and development. With this regional autonomy policy, it is hoped that the relevant regional government can regulate and manage its own household and to increase the efficiency of regional government administration in the context of serving the community and implementing development. With regional autonomy, it is also expected to be able to encourage improvement in the management of resources owned by each region. Regional autonomy has a broad impact on the regional authority to explore and manage sources of regional income in the context of development and community welfare in the region. In the general tax collection system in Indonesia, adopting a selfassessment system, where taxpayers are given the trust to be able to calculate, calculate, and pay their own taxes owed, so that through this system the implementation of tax administration is expected to be carried out in a neat, controlled, simple and easy manner. to be understood by members of the taxpayer community ${ }^{5}$.

\footnotetext{
2 Marihot, Pajak Bumi dan Baangunan di Indonesia (teori dan praktik),(Yogyakarta: Graha Ilmu, 2009), hal. 4

${ }^{3}$ Ibid, hal. 5
}

4 Redaksi Majalah Berita Pajak, Meninjau Sejarah Perkembangan IPEDA Sebelum Era PBB, (Jakarta: Majalah Berita Nomor 1186), hlm. 38

${ }^{5}$ Padmo Wahjono, Undang-Undang Perpajakan Beserta Penjelasan dan Peraturan Pelaksanaan, Ghalia Indonesia, Jakarta, 1984, hlm. 51. 
Based on Law Number 33 of 2004 concerning Financial Balance between the Central Government and Regional Governments, Regional Original Revenue is the income obtained by the regions which is collected based on Regional Regulations in accordance with statutory regulations. This Regional Original Revenue is sourced from Regional Taxes, Regional Levies, Separated Regional Assets Management Results and other legitimate Regional Original Revenues with the aim of giving freedom to regions in exploring and seeking funding in the implementation of regional autonomy as a manifestation of decentralization. So far, the potential sources of finance are controlled by the central governmentll. This shows that if an area's own regional income increases, the funds owned by the regional government will also increase. This increase will benefit the local government because it can be used for regional needs and development (Murjiyanto and Ismaya, 2016).

The 1945 Constitution of the Republic of Indonesia explains that the administration of taxes granted to the Regional Government is carried out by granting the broadest authority accompanied by the granting of rights and obligations to implement regional autonomy which is a unitary system of the Central Government administration. (Based on Law No. 12 of 2008 concerning the Second Amendment to Law No. 32 of 2004 concerning Regional Government and Law No. 33 of 2004 concerning Financial Balance between the Central Government and Regional Governments). (Sutrisna, 2020)

\section{Conclusion}

The results of this study indicate that the determination of NJOP is transferred to the local government followed by two other types of taxes PBB P2 and BPHTB due to the need for acceleration of regional development and regional autonomy and decentralization. The object of the tax, namely land and buildings, is an object that cannot be moved because it is included in the category of immovable objects, it is appropriate to be used as a local tax, because the local government located in each of these regions is more aware of the condition of the object of the tax compared to the central government. So that the transition referred to in the Law on Regional Taxes and Regional Levies covers the entire management, namely, implementation, determination of NJOP, tax collection, collection, data collection and making local regulations on BPHTB taxes as buyer's tax in the deed of sale and purchase.

\section{REFERENCES}

[1] Murjiyanto, R. and Ismaya, S. (2016) 'Determining the Choice of the Selling Value of Land and Building Tax Objects as the Basis for Calculation of Fees for Acquisition of Rights on Land and Buildings )', 23(1), pp. 142-161.

[2] United Nations, P. and Kota, DI (no date) 'ANALYSIS OF THE DETERMINATION OF NJOP AND ITS IMPLICATIONS ON PBB RECEIVING IN MANADO CITY', 1(3), pp. 484 493.

[3] Sutrisna, BE (2020) 'LEGAL CERTAINTY IN DETERMINING THE BASIS OF TRANSFER OF LAND RIGHTS FOR PAYING OF DUTY FOR THE ACQUISITION OF LAND AND BUILDING RIGHTS IN CIANJUR DISTRICT IS RELATED TO THE PRINCIPLE OF JUSTICE Boris', 3(1).

[4] Juridical Review of Income Tax Collection on Sale and Purchase Transactions of Land and/or Building Rights' (2018) Pandecta: Research Law Journal. doi:10.15294/pandecta.v12i2.9950.

[5] Marihot, Land and Building Tax in Indonesia (theory and practice), (Yogyakarta: Graha Ilmu, 2009), p. 4

[6] Ibid, p. 5

[7] Tax News Magazine Editor, Reviewing the History of IPEDA Development Before the UN Era (Jakarta: News Magazine Number 1186), p. 38

[8] Ovelia Veradina Imbing, Analysis of NJOP Determination and implications for $P B B$ acceptance in Manado City, ISSN $2303-1174$, EMBA Journal, Vol. 1 No. June 3, 2013, p. 485 